
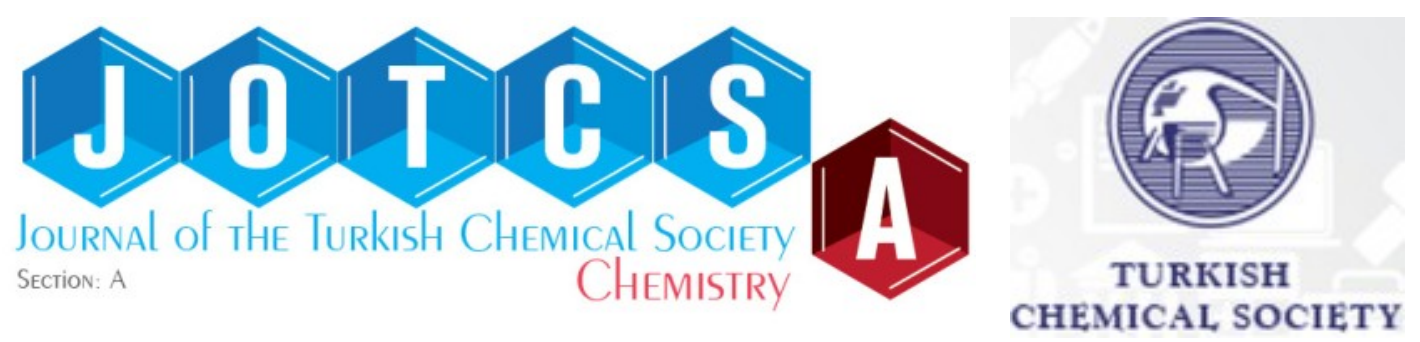

\title{
Density Functional Theory (DFT) Approach for Kinetic and Thermodynamic Study of Reaction Mechanism of Copper(II) Complex from 2-hydrazinyl-4,5-dihydro-1h-imidazole and anthracene-9- carbaldehyde
}

\author{
Shola Elijah Adeniji ${ }^{*} \square$ \\ ${ }^{1}$ Chemistry Department, Ahmadu Bello University, Zaria-Nigeria
}

\begin{abstract}
A computational approach was employed to study the reaction mechanism for the copper(II) complex from 2-hydrazinyl-4,5-dihydro-1H-imidazole and anthracene-9-carbaldehyde at DFT (B3LYP) theory level. The reaction mechanism was proposed and found to have five elementary steps which involve intermediate elementary step and three transition states. The reaction mechanisms are observed to have bimolecular and unimolecular steps which give rise to two-step reaction pathway. The bimolecular step appeared to be rate determining step with highest energy barrier $(2925.75 \mathrm{~kJ} / \mathrm{mol})$ at the third transition state (TS3). The geometrical variations in bond length of the intermediate and the transition states during the course of the reaction were also studied which signified that transformation has occurred from the initial state to a final state of product formation. The rate equation and general rate law for the reaction pathways were also established. The kinetics study shows that the reaction mechanism for the formation of copper(II) complex follows the pseudo-first order and second order reaction with high correlation, while the thermodynamic study indicates that the overall reaction is non-spontaneous and endothermic.
\end{abstract}

Keywords: Bimolecular, Copper(II) complex, kinetics, Transition state, Rate law.

Submitted: February 15, 2019. Accepted: October 11, 2019.

Cite this: Adeniji SE. Density functional theory (DFT) approach for kinetic and thermodynamic study of reaction mechanism of copper(II) complex from 2-hydrazinyl-4,5-dihydro-1h-imidazole and anthracene9-carbaldehyde. JOTCSA. 2020; 7(1): 77-86.

DOI: https://doi.org/10.18596/jotcsa.527827.

Corresponding Author. E-mail: shola4343@gmail.com.

\section{INTRODUCTION}

Compounds containing nitrogen are very widely distributed in nature, play significant roles in the metabolic activities of all living organisms. At present, imine functionality is found in $60-80 \%$ of the chemical compounds which accounts for the biological activities due to the nitrogen units. The synthesis of peptide antibiotics and other bio-active compounds are as a result of stereoselectivity of imines.
Schiff base which is a derivatives of imine with $\mathrm{N}$ containing ligands have been reported to have significant biological activities $(1,2)$. Recently, the pharmacological and biological activities of copper(II) complexes with $\mathrm{N}$-containing ligands have been studied extensively and linked with the DNA cleavage and intercalation. The mitochondrial activation pathway for cell apoptosis via the redox activity of the copper(II) center has also been reported $(3,4)$. (5) reported the synthesis and antitumor mechanisms of a copper(II) complex of anthracene-9-imidazoline hydrazone (9-AIH). However, the reaction 
mechanisms, the thermodynamic and kinetic parameters of the synthesized complex are not explained. To the best of our knowledge, literature on theoretical and computational evaluation of kinetic and thermodynamic parameters on the reaction mechanisms of this complex is not yet carried out.

The advents of computational techniques help to predict the mechanism of new systems and explore the chemical relativities of different systems. Semi-empirical models such as PM3, AM1, DFT and MNDO are computational approaches employed to study and examine system(s) that have complicated reaction mechanism within short period of time. Meanwhile, computational study with Density Functional Theory (DFT) approach give more accurate results than Semi-empirical method. The use of computational technique to monitor reaction and proposed reaction mechanisms have been reported by some of the researchers (6-9). Therefore, this study attempts to provide more information in this area by using theoretical and computational methods to elucidate the reaction mechanism, rate equations and derive the rate law for the formation of copper(II) complex from 2-hydrazinyl-4,5-dihydro-1H-imidazole and anthracene-9-carbaldehyde.

\section{COMPUTATIONAL METHODOLOGY}

\section{Structure optimization}

The 2D molecular structure presented in Scheme 1 and 2 were drawn by the Chemdraw software. The compounds were exported from 2D structure to 3D format using the Spartan 14 V1.1.4 Wave Function programming software. The entire three dimensions (3D structures) were geometrically optimized by minimizing energy. Molecular mechanics force field (MMFF) approach was employed to minimize the compounds in order to remove strain energy. Thereafter, the total geometric optimization of the molecular structures was achieved using Density Functional Theory DFT (B3LYP) (10).<smiles>NNC1=NCCN1</smiles>

Scheme 1. The synthetic route of synthesis copper(II) complex from 2-hydrazinyl-4,5-dihydro-1Himidazole and anthracene-9-carbaldehyde. (5)

\section{Structure optimization}

Fundamental reaction coordinate calculation and molecular properties were achieved with the aid of Spartan 14 V1.1.4 Wave Function programming software at DFT level. Activating energy $(\mathrm{Ea})$, rates $(\mathrm{k})$ reaction, the enthalpy of the reaction and equilibrium constants (Keq) were all computed using the expressions (1) (5) given below:

$$
\begin{aligned}
& E a=\Delta H+\mathrm{RT} \\
& k_{(298.15 K)}=\frac{K_{B} T}{h c^{o}} e^{-\Delta G^{\#} / R T}
\end{aligned}
$$

$$
\begin{aligned}
& k_{(298.15 K)}=\frac{K_{B} T}{h c^{o}} e^{-\Delta G^{0} / R T} \\
& k e q_{(298.15 K)}=e^{-\Delta G^{\#} / R T}
\end{aligned}
$$

$\mathrm{A}=\Delta K_{(298.15 K)} e^{-E_{a} / R T}$

where $\mathrm{k}(298.15 \mathrm{~K})$ is the reaction rate at temperature $(298.15 \mathrm{~K}) ; \mathrm{K}_{\mathrm{B}}$ is the Boltzmann constant $\left(1.380662 \times 10^{-23} \mathrm{~J} / \mathrm{K}\right) ; \quad T$ is temperature $(298.15 \mathrm{~K}) ; \mathrm{h}$ is Planck's constant 
$\left(6.626176 \times 10^{-34} \mathrm{Js}\right) ; \mathrm{c}^{0}$ is concentration (taken as unity); $\mathrm{R}$ is the molar gas constant ( 8.31441 $\mathrm{J} / \mathrm{mol} / \mathrm{K})$.

\section{RESULTS AND DISCUSSION}

A computational approach was employed to study the reaction mechanism for the copper(II) complex from 2-hydrazinyl-4,5-dihydro-1Himidazole and anthracene-9-carbaldehyde at DFT theory level. The Scheme 2 and 3 show the proposed $2 \mathrm{D}$ and $3 \mathrm{D}$ reaction mechanism and schematic diagram for the formation of copper(II) complex. Figure 1 shows the energy profile the of the relative electronic energy of reaction while Tables $1,2,3$ and 4 respectively, present the molecular properties, thermodynamics, kinetic parameters of the computed reaction mechanism and of variation in bond length. The reaction mechanism involves three activation complexes (transition state) and intermediate elementary steps. The mechanism is a two-step reaction pathway with bimolecular and a unimolecular step as shown in Scheme 2 and 3 .

In the scheme, the mechanism began with partial cleavage of the $\mathrm{C}=\mathrm{O}$ and $\mathrm{N}-\mathrm{H}, \mathrm{C}-\mathrm{N}$ and $\mathrm{O}-\mathrm{H}$ with an observed activation energy of +2664.84 $\mathrm{kJ} / \mathrm{mol}$ at the first transition state $\left(\mathrm{TS}_{1}\right)$. The first $\left(\mathrm{TS}_{1}\right)$ formation is endothermic with Gibbs' free energy found to be non-spontaneous. The first transition state $\left(\mathrm{TS}_{1}\right)$ proceeds to form the intermediate (INT) through $\mathrm{O}-\mathrm{H}$ single bond formation, $\mathrm{C}-\mathrm{N}$ single bond formation, $\mathrm{C}=\mathrm{O}$ bond cleavage to the single bond formation and $\mathrm{N}-\mathrm{H}$ single bond cleavage with their corresponding bond length presented in Table 4. The intermediate has a lower stabilization energy of $(144.34 \mathrm{~kJ} / \mathrm{mol})$ and non-spontaneous step $(+54.42 \mathrm{~kJ} / \mathrm{mol})$ lower than the activated complex $\left(\mathrm{TS}_{1}\right)$ as shown in Figure 1 below. The intermediate state is found to be endothermic and non-spontaneous which is accomplished through $\mathrm{C}=\mathrm{N}, \mathrm{O}-\mathrm{H}$ bond formation and $\mathrm{N}-\mathrm{H}$ bond cleavage with an energy barrier of 2624.95 $\mathrm{kJ} / \mathrm{mol}$. The intra-molecular interaction of the intermediate state proceeds to form the second transition state $\left(\mathrm{TS}_{2}\right)$ via the $\mathrm{C}=\mathrm{N}$ double bond formation, $\mathrm{O}-\mathrm{H}$ single bond formation, $\mathrm{N}-\mathrm{H}$ single bond cleavage and $\mathrm{C}-\mathrm{O}$ bond cleavage. The second transition state $\left(\mathrm{TS}_{2}\right)$ has the higher activation energy of $(2814.95 \mathrm{~kJ} / \mathrm{mol})$, enthalpy of $(334.34 \mathrm{~kJ} / \mathrm{mol})$ and Gibb's free energy of $(+88.13 \mathrm{~kJ} / \mathrm{mol})$. The transition state $\left(\mathrm{TS}_{2}\right)$ formed the first product (2-(2-(anthracen-9ylmethylene)hydrazinyl)-4,5-dihydro-1H-

imidazole) via cleavage bond of $\mathrm{C}-\mathrm{O}$ bond and successful removal of the molecule. The first product formed reacted with the copper(II) chloride to form the third transition state $\left(\mathrm{TS}_{3}\right)$ which is accomplished through $\mathrm{Cu}-\mathrm{N}_{1}$ and $\mathrm{Cu}-\mathrm{N}_{3}$ partial bond formation with an energy barrier of $(2925.75 \mathrm{~kJ} / \mathrm{mol})$. The interaction is found to be endothermic and non-spontaneous with (445.12 $\mathrm{kJ} / \mathrm{mol})$ and $(+90.14 \mathrm{~kJ} / \mathrm{mol})$ respectively. Finally, through $\mathrm{Cu}-\mathrm{N}_{1}$ and $\mathrm{Cu}-\mathrm{N}_{3}$ partial bond formation, the third transition state $\left(\mathrm{TS}_{3}\right)$ form the second product copper(II) complex of anthracene-9-imidazoline hydrazine). Unimolecular and bimolecular were the two consecutive steps competing for the reaction rate determination, but as a result of the highest energy barrier $(2925.75 \mathrm{~kJ} / \mathrm{mol})$ at the third transition state $\left(\mathrm{TS}_{3}\right)$ as shown in Figure 1 , the bimolecular step is considered to be the ratedetermining step. The two-step reaction mechanism presented by the potential and free energy profiles shows that the overall transformation is endothermic while Gibbs' free energy for each elementary step reported in Table 3 indicate that the reaction is nonspontaneous. The kinetics parameters reported in Table 3 shows that the reaction mechanism follows the pseudo-first order and second order reaction.

Variations in bond length as the reaction progress from transition state to intermediate were reported Table 4. A Decrease of about $0.05 \AA$ in $\mathrm{N}_{1}-\mathrm{C}_{1}$ bond length as the reaction proceeds from $\mathrm{TS}_{1}$ to INT was observed while an increase of $0.03 \AA$ was observed as the reaction proceeds from INT to $\mathrm{TS}_{2}$. The bond length also decreases with $0.02 \AA$ in $\mathrm{C}_{1}-\mathrm{O}$ as the reaction proceed from $\mathrm{TS}_{1}$ to INT while an increase of 0.06 was observed as the reaction proceed to $\mathrm{TS}_{2}$. A similar trend was observed in $\mathrm{Cu}-\mathrm{N} 1$ with variation in bond length of $0.168 \AA$ and $0.134 \AA$ as the reaction progresses from the third transition state $\left(\mathrm{TS}_{3}\right)$ to the final product. Also, the same trend was also noticed in $\mathrm{Cu}-\mathrm{N}_{3}$ with variation in bond length of $0.154 \AA$ and $0.136 \AA$ as the reaction progresses from the third transition state to the final product. All these variations that arise from the aforementioned states signified that transformation has occurred from the initial state to a final state of product formation. 


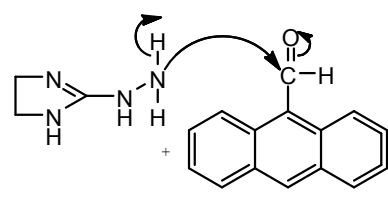

$\mathbf{M}+\mathbf{N}$<smiles>[Y4]C1CCCC1</smiles>

Transition state $\left(\mathrm{TS}_{1}\right)$

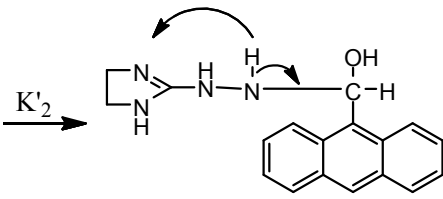

Intermediate (INT)

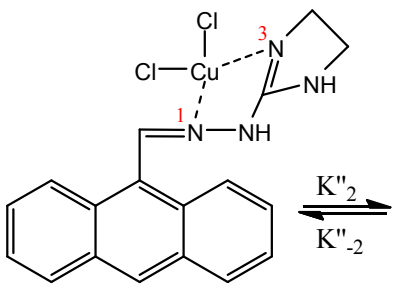

Transition state $\left(\mathrm{TS}_{3}\right)$
$\mathrm{CuCl}_{2}+$<smiles></smiles>

$\mathbf{P}_{1}$

$\downarrow \mathrm{K}^{\prime \prime}$<smiles>ClC1(Cl)N2CCN1C(N/N=C/c1c3ccccc3cc3ccccc13)N2</smiles>

$\mathbf{P}_{2}$

Scheme 2. 2D structure of reaction mechanism for the formation of copper(II) complex.

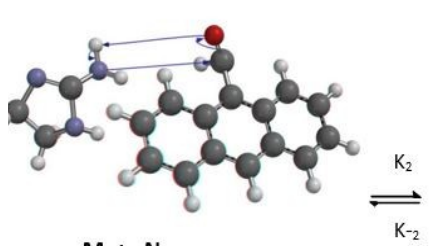

$\mathrm{M}+\mathrm{N}$

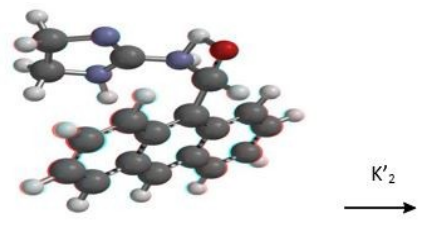

Transition state $\left(\mathrm{TS}_{1}\right)$

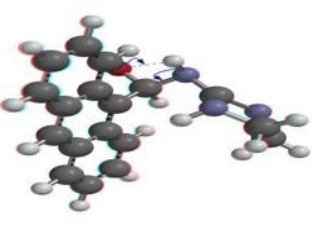

Intermediate (INT)

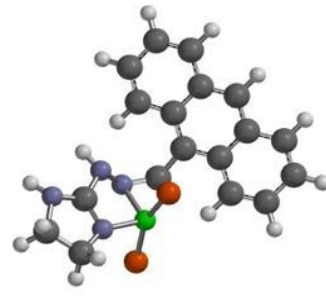

Transition state $\left(\mathrm{TS}_{3}\right)$
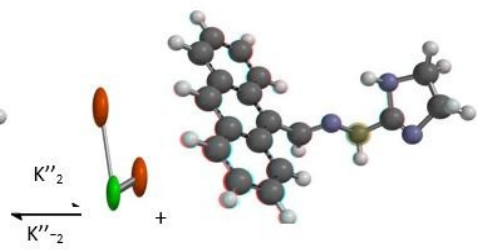

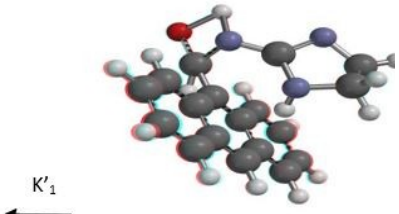

Transition state $\left(\mathrm{TS}_{2}\right)$

$\downarrow \mathrm{K}_{1}^{\prime \prime}$

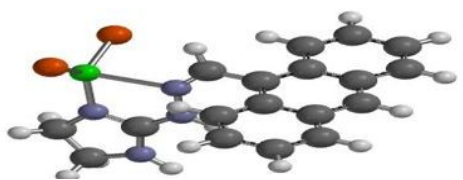

Scheme 3. 3D structure of reaction mechanism for the formation of copper(II) complex. Key: $\mathbf{M}=2-$ hydrazinyl-4,5-dihydro-1H-imidazole, $\mathbf{N}=$ anthracene-9-carbaldehyde, $\mathbf{P 1}=2$-(2-(anthracen-9ylmethylene)hydrazinyl)-4,5-dihydro-1H-imidazole, $\mathbf{Q}=$ copper(II)chloride, $\mathbf{P} \mathbf{2}=$ copper(II) complex of anthracene-9-imidazoline. 
500

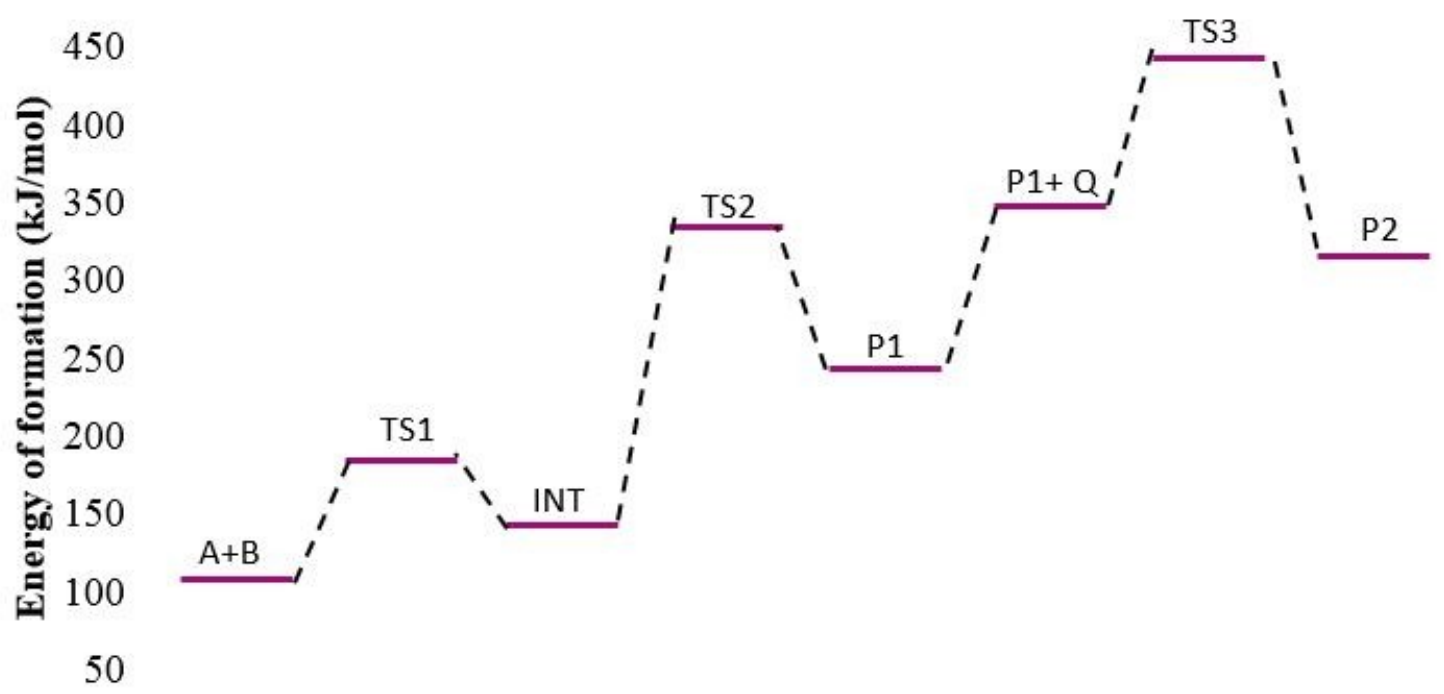

0

\section{Reaction path}

Figure 1: Profiles of the potential energy surface for copper(II) complex from 2-hydrazinyl-4,5-dihydro$1 \mathrm{~h}$-imidazole and anthracene-9-carbaldehyde.

Mechanism and derived rate law of the where " $\mathrm{P}_{1} \mathrm{Q}^{\# \prime}$ " represent the third Transition state

\section{Reaction}

From reaction scheme given above, the reaction mechanism, rate equations and derived rate law for copper(II) complex form 2-hydrazinyl-4,5dihydro-1H-imidazole and anthracene-9carbaldehyde are expressed below:

$\mathrm{M}+\mathrm{N} \underset{\mathrm{K}_{-2}}{\stackrel{\mathrm{K}_{2}}{\rightleftharpoons}} \mathrm{MN}^{\#}$

where "MN" represent the first Transition state $\left(\mathrm{TS}_{1}\right)$

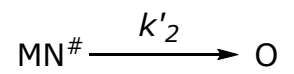

where " $\mathrm{O}$ " represent the Intermediate state (INT)

$\mathrm{O} \underset{\mathrm{K}_{-1}}{\stackrel{\mathrm{K}_{1}}{\rightleftharpoons}} \mathrm{O}^{\#}$

where "O" represent the second Transition state $\left(\mathrm{TS}_{2}\right)$

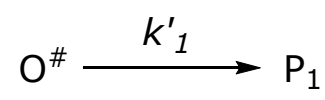

$\mathrm{P}_{1}+\mathrm{Q} \underset{k_{-2}^{\prime \prime}}{\stackrel{k^{\prime \prime}}{\rightleftharpoons}} \mathrm{P}_{1} \mathrm{Q}^{\#}$ $\left(\mathrm{TS}_{3}\right)$

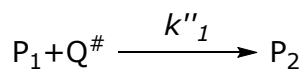

The rate law for the first product $\left(P_{1}\right)$ is derived below;

$\frac{d\left[P_{1}\right]}{d t}=\mathrm{k}_{1}{ }_{1}\left[\mathrm{O}^{\#}\right]$

$\frac{d\left[\mathrm{o}^{\#}\right]}{d t}=-\mathrm{k}^{\prime}\left[\mathrm{O}^{\#}\right]-\mathrm{k}_{-1}\left[\mathrm{O}^{\#}\right]+\mathrm{k}_{1}[\mathrm{O}]$

$\frac{d[0]}{d t}=-\mathrm{k}[0]+\mathrm{k}_{-1}\left[\mathrm{O}^{\#}\right]+\mathrm{k}_{2}{ }_{2}\left[\mathrm{MN}^{\#}\right]$

$\frac{d\left[\mathrm{MN}^{*}\right]}{d t}=-\mathrm{k}_{2}\left[\mathrm{MN}^{\#}\right]-\mathrm{k}_{-2}\left[\mathrm{MN}^{\#}\right]+\mathrm{k}_{2}[\mathrm{M}][\mathrm{N}]$

Applying steady state approximation, Equation (7) becomes;

$\left[\mathrm{O}^{\#}\right]=\frac{k_{1}}{k_{1}^{\prime}+k_{-1}}[\mathrm{O}]$

Substitute Equation (8) in (10)

$[\mathrm{O}]=\frac{k_{2}^{\prime}\left(k_{1}^{\prime}+k_{-1}\right)\left[\mathrm{MN}^{\#}\right]}{k_{1} k_{1}^{\prime}}$

Similarly, from Equation (9) we have

$\left[\mathrm{MN}^{\#}\right]=\frac{k_{2}}{k_{2}^{\prime}+k_{-2}}[\mathrm{M}][\mathrm{N}]$ 
Equation (11) and (12) yield

$[0]=\frac{k_{2}^{\prime} k_{2}\left(k_{1}^{\prime}+k_{-1}\right)[\mathrm{MN} \#]}{k_{1} k_{1}^{\prime}\left(k_{2}^{\prime}+k_{-2}\right)}$

From Equation (13) and (10), we have

$\left[\mathrm{O}^{\#}\right]=\left(\frac{k_{2}^{\prime} k_{2}}{k_{2}^{\prime}+k_{-2}}\right)[\mathrm{M}][\mathrm{N}]$

Substituting Equation (14) in (6), the overall rate law for the first product will be written as;

$\frac{d\left[P_{1}\right]}{d t}=k^{\prime}{ }_{1}\left(\frac{k_{2}^{\prime} k_{2}}{k_{2}^{\prime}+k_{-2}}\right)[\mathrm{M}][\mathrm{N}]$

The rate law for the second product $\left(P_{2}\right)$ is derived below;

$$
\frac{d\left[P_{2}\right]}{d t}=k_{1}^{\prime \prime}\left[P_{1} Q^{\#}\right]
$$

$\frac{d\left[P_{1} \mathrm{Q}^{\#}\right]}{d t}=-k_{1}^{\prime \prime}\left[P_{1} \mathrm{Q}^{\#}\right]-k_{-2}^{\prime \prime}\left[P_{1} \mathrm{Q}^{\#}\right]+k_{2}^{\prime \prime}\left[P_{1}\right][\mathrm{Q}]$

Applying steady state approximation Equation (17) becomes;

$$
\left[P_{1} \mathrm{Q}^{\#}\right]=\left(\frac{k_{2}^{\prime \prime}}{k_{1}^{\prime \prime}+k_{-2}^{\prime \prime}}\right)\left[P_{1}\right][\mathrm{Q}]^{\text {‘ }}
$$

Substituting Equation (18) in (16), the overall rate law for the second product will be written as;

$$
\frac{d\left[P_{2}\right]}{d t}=k_{1}^{\prime \prime}\left(\frac{k_{2}^{\prime \prime}}{k_{1}^{\prime \prime}+k_{-2}^{\prime \prime}}\right)\left[P_{1}\right][Q]
$$

\section{CONCLUSION}

A reaction mechanism for the copper(II) complex from 2-hydrazinyl-4,5-dihydro- $1 \mathrm{H}$-imidazole and anthracene-9-carbaldehyde have been investigated at the DFT theory level. The mechanism of the reaction was found to consist of three transition states with the bimolecular and unimolecular step. The bimolecular step was found to be the rate-determining step with the highest energy barrier of $2925.75 \mathrm{~kJ} / \mathrm{mol}$ at the third transition state $\left(\mathrm{TS}_{3}\right)$ while the fastest reaction is observed with the unimolecular step. The rate laws have been derived for the reaction mechanism. The kinetics study shows that the reaction mechanism follows the pseudo-first order and second order reaction with high correlation while the thermodynamic study shows that the overall reaction is endothermic and nonspontaneous.

\section{REFERENCES}

1. Kostova I, Saso L. Advances in research of Schiff-base metal complexes as potent antioxidants. Curr Med Chem. 2013; 20(36): 4609-32.

2. Sztanke K, Maziarka A, Osinka A, Sztanke M. An insight into synthetic Schiff bases revealing antiproliferative activities in vitro. Bioorg Med Chem. 2013; 21(13): 3648-66.

3. Maheswari PU, Roy S, den Dulk H, Barends S, van Wezel G, Kozlevcar B, et al. The squareplanar cytotoxic [CuII (pyrimol) $\mathrm{Cl}$ ] complex acts as an efficient DNA cleaver without reductant. ] Am Chem Soc. 2006; 128(3): 710-11.

4. Qiao X, Ma Z-Y, Xie C-Z, Xue F, Zhang Y-W, $\mathrm{Xu} J-Y$, et al. Study on potential antitumor mechanism of a novel Schiff Base copper(II) complex: synthesis, crystal structure, DNA binding, cytotoxicity and apoptosis induction activity. J Inorg Biochem. 2011; 105(5): 728-37.

5. Qin Q-P, Liu Y-C, Wang H-L, Qin J-L, Cheng FJ, Tang S-F, et al. Synthesis and antitumor mechanisms of a copper(II) complex of anthracene-9-imidazoline hydrazone (9-AIH). Metallomics. 2015; 7(7): 1124-36.

6. Ambundo EA, Deydier M-V, Ochrymowycz L, Rorabacher $D$. Kinetics and mechanism of copper(II) complex formation with tripodal aminopolythiaether and aminopolypyridyl ligands in aqueous solution. Inorg Chem. 2000; 39(6): 1171-79.

7. Jasiński R, Jasińska E, Dresler E. A DFT computational study of the molecular mechanism of $[3+2]$ cycloaddition reactions between nitroethene and benzonitrile $\mathrm{N}$-oxides. J Mol Model. 2017; 23(1): 13.

8. Siaka A, Adamu U, Sulaiman I, Hamza A, others. Density functional theory (B3LYP/6-311+ $\mathrm{G}^{* *}$ ) study of some semicarbazones formation mechanism. Orient J Chem. 2015; 31(4): 198597.

9. Siakaa A, Uzairub A, Idrisb S, Abbaa H. DFT (B3LYP) computational study on the mechanisms of formation of some semicarbazones. Chem J Mold Gen. 2016; 11(1): 74-85.

10. Adeniji SE, Uba S, Uzairu A. A Novel QSAR Model for the Evaluation and Prediction of (E)-N'Benzylideneisonicotinohydrazide Derivatives as the Potent Anti-mycobacterium Tuberculosis Antibodies Using Genetic Function Approach. Phys Chem Res. 2018; 6(3): 479-92. 
Table 1. Calculated molecular properties for copper(II) complex from 2-hydrazinyl-4,5-dihydro-1H-imidazole and anthracene-9-carbaldehyde using DFT at $298.15 \mathrm{~K}$.

\begin{tabular}{|c|c|c|c|c|c|c|c|c|c|}
\hline $\begin{array}{l}\text { Reacting } \\
\text { species }\end{array}$ & Formular & $\begin{array}{c}\text { Energy } \\
\text { (Vacuum) } \\
(\mathrm{kJ} / \mathrm{mol})\end{array}$ & $\begin{array}{c}\text { Energy } \\
(\mathrm{aq}) \\
(\mathrm{kJ} / \mathrm{mol})\end{array}$ & $\begin{array}{c}\text { Solvation } \\
\text { Energy } \\
(\mathrm{kJ} / \mathrm{mol})\end{array}$ & $\begin{array}{c}\text { Weight } \\
\text { (amu) }\end{array}$ & $\begin{array}{l}\text { Point } \\
\text { group }\end{array}$ & $\begin{array}{c}\text { Dipole } \\
\text { Moment } \\
\text { (debye) }\end{array}$ & $\begin{array}{c}\text { E HOMO } \\
\text { (ev) }\end{array}$ & $\begin{array}{c}\text { E LUMO } \\
\text { (ev) }\end{array}$ \\
\hline A & $\mathrm{C}_{3} \mathrm{H}_{8} \mathrm{~N}_{4}$ & 41.43 & 77.54 & -63.90 & 100.125 & $\mathrm{C}_{1}$ & 2.94 & -9.34 & 0.90 \\
\hline B & $\mathrm{C}_{15} \mathrm{H}_{10} \mathrm{O}$ & 51.71 & 54.73 & -2.26 .96 & 206.244 & $C_{s}$ & 2.56 & -8.45 & -1.22 \\
\hline $\mathbf{T S}_{1}$ & $\mathrm{C}_{18} \mathrm{H}_{17} \mathrm{~N}_{3} \mathrm{O}$ & 129.68 & 131.74 & -53.91 & 291.354 & $\mathrm{C}_{1}$ & 1.77 & -8.25 & -1.05 \\
\hline INT & $\mathrm{C}_{18} \mathrm{H}_{17} \mathrm{~N}_{3} \mathrm{O}$ & 107.96 & 110.07 & -62.93 & 291.354 & $\mathrm{C}_{1}$ & 2.63 & -8.32 & -1.12 \\
\hline $\mathbf{T S}_{2}$ & $\mathrm{C}_{18} \mathrm{H}_{16} \mathrm{~N}_{3} \mathrm{O}$ & 308.89 & 321.67 & -187.09 & 290.346 & $\mathrm{C}_{1}$ & 4.43 & -12.07 & -6.35 \\
\hline $\mathbf{P}_{\mathbf{1}}$ & $\mathrm{C}_{18} \mathrm{H}_{16} \mathrm{~N}_{4}$ & 83.06 & 94.23 & -60.75 & 288.354 & $\mathrm{C}_{1}$ & 2.03 & -8.34 & -1.14 \\
\hline C & $\mathrm{CuCl}_{2}$ & 77.74 & 89.43 & -126 & 134.45 & $\mathrm{C}_{2 \mathrm{~V}}$ & 3.65 & -16.58 & -8.89 \\
\hline $\mathbf{T S}_{3}$ & $\mathrm{C}_{18} \mathrm{H}_{16} \mathrm{CuCl}_{2} \mathrm{~N}_{4}$ & 357.7 & 376.34 & -176 & 422.806 & $\mathrm{C}_{1}$ & 9.91 & -10.67 & -6.31 \\
\hline $\mathbf{P}_{\mathbf{2}}$ & $\mathrm{C}_{18} \mathrm{H}_{16} \mathrm{CuCl}_{2} \mathrm{~N}_{4}$ & 143.98 & 157.54 & -143 & 422.81 & $\mathrm{C}_{1}$ & 8.40 & -11.13 & -5.85 \\
\hline
\end{tabular}




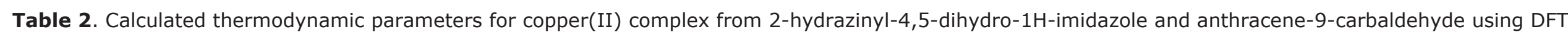
at $298.15 \mathrm{~K}$.

\begin{tabular}{|c|c|c|c|c|c|c|c|c|c|}
\hline $\begin{array}{l}\text { Reacting } \\
\text { Species }\end{array}$ & $\begin{array}{c}\mathrm{C}_{\mathrm{V}} \\
(\mathrm{J} / \mathrm{mol})\end{array}$ & $\begin{array}{c}\text { Zero } \\
\text { Point } \\
\text { Energy } \\
(\mathrm{kJ} / \mathrm{mol})\end{array}$ & $\begin{array}{c}\Delta^{\mathbf{H}^{0}(\mathbf{k J} /} \\
\mathrm{mol})\end{array}$ & $\begin{array}{c}\Delta^{\mathbf{S}^{0}} \\
(\mathrm{~kJ} / \mathrm{mol})\end{array}$ & $\begin{array}{c}\Delta^{\mathbf{G}^{0}} \\
(\mathrm{~kJ} / \mathrm{mol})\end{array}$ & $\begin{array}{c}\text { Ea } \\
(\mathrm{kJ} / \mathrm{mol})\end{array}$ & $\begin{array}{c}\Delta^{\mathbf{H}^{\#}(\mathbf{k J} /} \\
\mathrm{mol})\end{array}$ & $\begin{array}{c}\Delta^{\mathbf{S}^{\#}} \\
(\mathbf{k J} / \mathrm{mol})\end{array}$ & $\begin{array}{c}\Delta^{\mathbf{G}^{\#}} \\
(\mathbf{J} / \mathbf{m o l})\end{array}$ \\
\hline $\bar{A}$ & 30.63 & 44.11 & 48.87 & +0.23748 & 24.66 & 2529.48 & & & \\
\hline B & 48.42 & 44.54 & 56.85 & +0.3308 & 35.41 & 2537.46 & & & \\
\hline $\mathbf{T S}_{1}$ & 168.85 & 161.41 & & & & 2664.84 & 184.23 & +0.515 & 73.68 \\
\hline INT & 138.04 & 137.76 & 144.34 & +0.4149 & 54.42 & 2624.95 & & & \\
\hline $\mathbf{T S}_{2}$ & 164.48 & 310.34 & & & & 2814.95 & 334.34 & +0.4093 & 88.13 \\
\hline $\mathbf{P}_{1}$ & 164.14 & 224 & 243.88 & +0.4146 & 76.45 & 2724.49 & & & \\
\hline C & -22.59 & 94.18 & 104.32 & +0.196 & 63.13 & 2584.93 & & & \\
\hline $\mathbf{T S}_{3}$ & 192.63 & 423.70 & & & & 2925.75 & 445.12 & +0.4766 & 90.54 \\
\hline $\mathbf{P}_{2}$ & 163.65 & 345.5 & 317.75 & +0.4624 & 82.04 & 2798.36 & & & \\
\hline
\end{tabular}




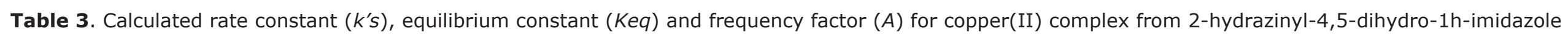
and anthracene-9-carbaldehyde using DFT at 298.15 K.

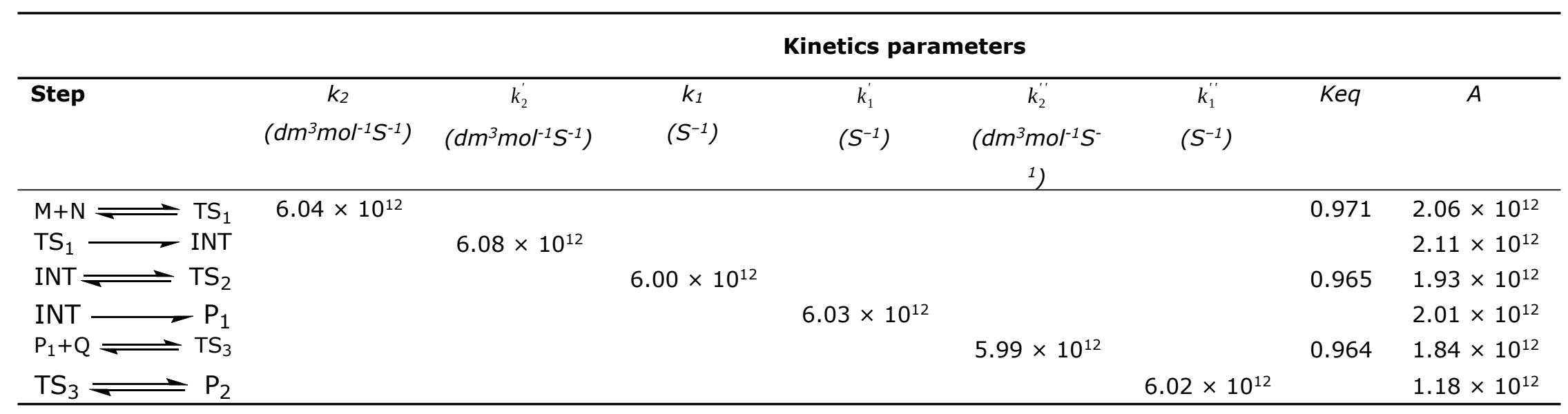


Table 4. Variations in bond length during transformation through $\mathrm{TS}_{1}, \mathrm{INT}, \mathrm{TS}_{2} \mathrm{TS}_{3}$ and $\mathrm{P}_{2}$

\begin{tabular}{|c|c|c|c|c|c|c|c|c|c|}
\hline $\mathbf{T S}_{1}$ & & INT & & $\mathbf{T S}_{2}$ & & $\mathbf{T S}_{3}$ & & $\mathbf{P}_{2}$ & \\
\hline \multirow[t]{3}{*}{ Bond } & Bond & Bond & Bond & Bond & length & Bond & Bond & Bond & Bond \\
\hline & length & & Length & & Bond & & Length & & Length \\
\hline & $(\AA)$ & & $(\AA)$ & & $(\AA)$ & & $(\AA)$ & & $(\AA)$ \\
\hline $\mathbf{N}_{1}-\mathbf{C}_{1}$ & 1.499 & $\mathrm{~N}_{1}-\mathrm{C}_{1}$ & 1.494 & $\mathrm{~N}_{1}-\mathrm{C}_{1}$ & 1.497 & $\mathrm{Cu}-\mathrm{N}_{1}$ & 1.886 & $\mathrm{Cu}-\mathrm{N}_{1}$ & 1.732 \\
\hline $\mathrm{C}_{1}-\mathrm{O}$ & 1.412 & $\mathrm{C}_{1}-\mathrm{O}$ & 1.409 & $\mathrm{C}_{1}-\mathrm{O}$ & 1.415 & $\mathrm{Cu}-\mathrm{N}_{3}$ & 1.930 & $\mathrm{Cu}-\mathrm{N}_{3}$ & 1.794 \\
\hline
\end{tabular}

